\title{
The Determinants of Stock Prices of European Football Clubs: An Empirical Analysis
}

\author{
Giampiero Maci $^{1}$, Vincenzo Pacelli², Elisabetta D’Apolito ${ }^{1}$ \\ ${ }^{1}$ Department of Economics, University of Foggia, Foggia, Italy \\ ${ }^{2}$ Ionian Department of Law and Economics of the Mediterranean: Society, Environment, Cultures, University of Bari “Aldo Moro”, Bari, \\ Italy
}

Email address:

elisabetta.dapolito@unifg.it(E. D’Apolito)

\section{To cite this article:}

Giampiero Maci, Vincenzo Pacelli, Elisabetta D’Apolito. The Determinants of Stock Prices of European Football Clubs: An Empirical Analysis. International Journal of Economics, Finance and Management Sciences. Vol. 8, No. 5, 2020, pp. 168-179.

doi: 10.11648/j.ijefm.20200805.11

Received: August 4, 2020; Accepted: August 17, 2020; Published: September 3, 2020

\begin{abstract}
This study investigates the sporting and financial performances impacts of football clubs on stock price dynamics. The sample covers all the European football companies listed on the Stock Exchange over the period 2012-2017. The stock price formation process for listed football companies is investigated through a multiple regression model in which the share price is a function of several variables of listed European football companies, because the authors analyze the impact of both sports and financial and management performance on the share prices of the companies. Panel data fixed effects estimations are employed to mitigate endogeneity concerns and to control for within-firm dynamics. It was found that on market performance: i) positively impacts of sports performance; ii) positively impacts of economic performance; iii) positively impacts of asset and revenue diversification. This topic would be of interest to international investors and will push club managers to nurture their own corporate culture, which, in many cases, is still not in keeping with the size or pace of market development. These findings have important implications for investors as well as club managers. The empirical research provides useful implications to direct club managements towards best practices that will help football clubs access capital markets. Indeed, they present an encouragement for the improvement of the competitive results and the economic-financial performances.
\end{abstract}

Keywords: Stock Prices, Football Clubs, Balance Sheet Indicators

\section{Introduction}

Over the last few years and with the advent of the digital age, the football industry has become the largest entertainment industry in Europe, outperforming any other sport and entertainment, from music, cinema or theater. In recent years, the turnover of the major European football companies has grown at a pace unknown to all the other economic sectors, driven by the development of the digital economy, media revenues and sponsorships.

This study aims to investigate the sporting and financial performances impacts of football clubs on stock price dynamics. The sample covers all the European football companies listed on the Stock Exchange over the period 2012-2017. Panel data fixed effects estimations are employed to mitigate endogeneity concerns and to control for within- firm dynamics.

The ordinary shares of football clubs are financial instruments that represent a portion of the share capital of the issuing sports companies, typically set up as a joint-stock company. The issue and subsequent trading of shares by football clubs is aimed at collecting financial resources in the form of risk capital.

In the case of shares issued by sports companies listed on the stock exchange - which is the case examined in the present research work -, however the formation of share prices in financial markets identifies liquid monetary values to which it is possible to dispose of - time to time - investment at current prices. The trading of equity securities in financial markets, therefore, generates for the shareholder potential cash flows in the form of both dividend and capital gain, where there is - at the time of the transaction - a positive difference between the 
price of sale and purchase of the stock.

The prices at which the shares are traded on the market reflect, at any time, the judgment of the same on the potential future income of the company and are the result of the comparison on the market between the actors of the demand and those of the stock offer. The market price of the listed stock is, in fact, defined - at any time - by the report that identifies the balance between the offer and the demand for the same stock.

Like any stock, even that of a listed football club should therefore rise when scenarios occur which presuppose or certify situations or events that legitimize the expectations of an increase in turnover, economic margins, efficiency levels or asset value assets and vice versa.

However, the investment in the stocks of football companies presents characteristics that increase their risk compared to other types of listed companies, namely:

1) the greater instability and therefore volatility due to the significant correlation between the performance of the securities and the sports results (which are by their nature uncertain and recurrent events during the sporting season) or the events of a merely fortuitous and therefore unpredictable nature, such as the injury of players, which could compromise the sports prospects and, consequently, the company's income, influencing in an absolutely unpredictable and fortuitous way the dynamics of the share price;

2) the greater instability and therefore volatility due to the significant correlation between the performance of the securities and the market value of the assets (in particular the players or the brand), which assets are equally linked to sports results and therefore extremely volatile.

In the financial markets, moreover, short-term expectations and long-term expectations manifest their effects on share prices. These expectations are formed, among other things, following decision-making mechanisms that are often absolutely irrational. They are further exacerbated for the football clubs listed due to the importance of the emotional component, linked above all to sports results, which characterizes the investment in securities shares of sports companies. The multiplication of irrational variables in the formation of short-term expectations, due essentially to the incomplete availability of quantitative and qualitative information useful for predicting - with an acceptable margin of reliability - the future returns of an investment, also makes the same expectations extremely volatile and strongly dependent on changes in operators' perceptions.

It is therefore possible to state that the knowledge of the variables capable of influencing the performance of any investment over time is scarce and, in this scenario of uncertainty, perceptions or - if you wish - emotions or hopes often irrational nature are inevitably of great importance of operators in guiding expectations. This inevitably raises attention to a new strategic and managerial frontier, especially for listed companies. This refers to the strategic importance assumed for sports companies by the ability to govern the variables capable of influencing investors' perceptions, also through effective external direct and indirect company communication. This is because the expectations of the operators are able to determine significant deviations of the prices of the stocks from their fundamental value, if only in the short term.

There are many examples in this sense, but a recent one that deserves to be mentioned is that linked to the item, published on May 23, 2019 by the journalist source AGI, of an imminent agreement between Juventus and the Spanish coach Guardiola to entrust him the bench of the Italian champion team. Juventus has been the ruler of the Italian championship for the last eight years, the only Italian company able to manage its own stadium. The club with the highest turnover and, in general, a solid equity company, with stable governance. Pep Guardiola, besides undoubtedly being a great coach, is also a global "personal brand" and his arrival would have represented the natural continuation, in a sporting and economic key, of the company policy started the previous year with the purchase of the footballer Cristiano Ronaldo (CR7). Guardiola is in fact a CR7 of the bench, capable of guaranteeing sports results but also new investors, sponsors, merchandising and therefore economically justifying his generous remuneration (newspapers spoke of an agreement of 24 million euros net per year, that is a figure never approached before for a coach or a footballer in Italy) with greater revenues of a commercial nature. Since May 23, 2019, the Juventus share price, fresh from elimination from the Champion League which had been followed by a loss of $18 \%$ in the value of the title on the day following its elimination (April 17, 2019) rose. Despite public denials by Guardiola and Manchester City (his previous club), the emotional wave feeds "more or less irrational passion fire" of the investor-fans or the shrewd speculators and the Juventus title earned about $30 \%$ in less than a month.

In this research work we analyzed the influence of sports performance of football clubs listed on their share prices as well as the relationship between the dynamics of share prices, competitive results, and the economic-financial performance of all the companies of European football listed on the Stock Exchange, in the period between 2012 and 2017. The stock price formation process for listed football companies is investigated through the multiple regression model in which the share price (dependent variable) is a function of several (independent) variables, to European football companies listed. This is because we analyzed the impact on the share prices of the companies of both the sports results and the business dynamics that influence the conditions of economic, financial and equity balance. This topic inevitably attracts the attention of international investors and pushes club managers to evolve their own corporate culture which in many cases is still not up to the size and development of the market.

The paper is structured as follows. In the next section, the theoretical background will be discussed to elaborate the research hypotheses. A preliminary analysis, the method and data will be presented in section three and four, respectively. The empirical results and The discussion of the main findings can be found in section five, while section six provides the 
conclusions, the implications and future research lines.

\section{Theoretical Background and Hypotheses Development}

In the regulated financial markets the prices at which securities are traded on the market incorporate the information and expectations of market operators on the fundamental economic variables that determine the value of the securities $[10,1]$ and are the result of the comparison on the market between the actors of the demand and those of the offer of the same stock $[15,8,22]$. Football titles are affected, albeit to varying degrees and with different intensities, by all the variables that determine its supply and demand and are more subject than others to speculation and volatility [12].

The study of the dynamics of share prices of football teams is an important research field within the financial economy of the football clubs, certainly given the greater volatility of such securities inevitably linked to sports results $[25,7,9,32$, $5,6,13]$, to the management and strategic actions undertaken by the companies [19], to the potentially profitable market of the football companies [24], to the soccer players' performance and skills and coaches [18, 11]. Empirical research shows that a good performance of the football title is generally preceded by a good sporting result [6] and, therefore, the link between sports results and stock market performance in European football seems particularly marked $[25,3,5,14,4,23,16,20]$. In this study, we consider the score of international tournaments $[2,29,21]$ (UEFA coefficient score) as a measure of sporting performance [17]. Therefore, based on these arguments, the first research hypothesis is as follows:

H1. There is a positive relationship between stock prices of football clubs and competitive results.

In general terms, moreover, it is reasonable to suppose that the investment choices of market operators are conditioned by a broad set of economic and financial variables of football clubs [31] as well as by macroeconomic and market variables. The influence of the financial indicators of the listed football companies has been found several times by scholars [30] who identify, through an econometric methodology, a moderate and significant relationship between the maximization of the profit of the football clubs and the prospects for return on the stock. Other analyzes (Oral C., 2016) conducted through the use of alternative regression models (GRA method), evaluate the influence of Liquidity Ratios (Current Assets/Short Term Loans; Current Assets-Inventories / Short Term Loans), of Leverage Ratios (Long Term Loans/Equity Capital; Total Debts / Total Assets; Short Term Loans / Total Debts; Total Assets/Equity Capital) and Profitability Ratios (Gross Profit / Net Sales, Net Profit / Net Sales, Net Profit / Total Assets, Net Profit / Equity Capital) on stock prices of football clubs listed on the Istanbul Stock Exchange. These analyzes show that the variables able to explain the performance of the stock market quotations are mainly those of profitability. Similarly, various studies [28] conducted through the use of regression models, assess whether the influence of budgetary indicators (such as turnover, the costs related to the performance of players, commissions related to transactions, amortization and net operating revenues) remains even in the presence of adjustments for risk factors, attributed, for example, to investors' expectations regarding the management's performance in generating or not generating value with respect to the accounting value. These analyzes show a direct and significant relationship between the financial variables and the performance of the quotations on the stock exchange; a significant relationship with risk is not evident, analyzed through the standard deviation of the share return, which depresses the value of share prices. Therefore, based on these arguments, the second research hypothesis is as follows:

$\mathrm{H} 2$. There is a positive relationship between the market performance and the economic-financial profile of football clubs.

In this work all the financial statements of the listed European football companies have been analyzed and the Balance Sheet and Income Statement formats have been reclassified and the main financial, economic and management variables (efficiency and management) have been analyzed. The present work therefore aims to provide a contribution to the existing literature on the subject in the following way: 1) analyzing the influence of the sports performances of all the football clubs listed on their share prices; 2) empirically investigating the sensitivity of stock prices of all European football companies listed on the stock exchange to changes in competitive results, balance sheet and management indicators of the companies surveyed, even in the awareness that in the process of formation of share prices other variables also take on fundamental importance, such as the emotional components as well as corporate and noncorporate phenomena and events that are difficult to reduce; 3) examining the sports, internal and jointly and estimating the relationship with the price of the shares; 4) conducting the analysis on the entire population of football clubs listed in the 2012-2017 period.

\section{Sports Results and Stock Prices: A Preliminary Analysis}

In the preliminary empirical analysis, carried out both at the level of a single listed European company and at an aggregate level, it was investigated what impact the sports results achieved by the company at time $\mathrm{T}$ on its share prices had on the following day of listing (closing price per day $\mathrm{T}+1$ ).

As far as sports results are concerned, competitions refer to all national championship matches and international cups played in the period between 2004 and 2015, for a total of 9793 games. The overall victories were 5185, draws 2257 , defeats 2351.

Considered "T" on the day of the analyzed sports competition, the share prices of the companies (daily closing price) were analyzed on the following days: 
1) $\mathrm{T}-1$, or the closing price of the day preceding the match or of the same day if the game is played in the week in the evening (after the market closes). So the price of Friday night if you play on the weekend or the price on Tuesday night if the game is played Tuesday evening (after the market closes);

2) $\mathrm{T}+1$, or the closing price of the day following the match. So the price of Monday night if you play on the weekend or the price of Wednesday night if the game is played on Tuesday evening (after the market closes).

Tables 1 and 2 show the summary data relating to the performance of the individual teams' titles the day after the meetings examined $(T+1)$, while the aggregated results are shown in tables 3 .

The analysis shows that in the case of a positive competitive result (victory), the securities have a positive performance in $44.40 \%$ of cases, negative in $35.39 \%$ of cases, while $20.21 \%$ of the time the prices remain unchanged. A defeat, instead, is followed in $61 \%$ of the cases by a negative performance of the courses, in $22.42 \%$ of the cases by a price increase and in $16.59 \%$ of the cases by no variation. A draw is generally associated with a defeat, in fact in $54.81 \%$ of cases there is a reduction in prices, in $26.58 \%$ of cases a positive performance, while $18.61 \%$ of the times prices do not change. It is possible to point out that the link between sports results and course performance is more pronounced in cases of defeat or draw, when there is a reduction in prices in more than $50 \%$. In addition to purely economic reasons, this can also be traced to the consideration that the owners of football titles are often fans and therefore tend to be emotionally tied to their favorite team and irrationally optimistic about their chances of success. Therefore when a defeat or a draw occurs, the negative feeling that results tends to irrationally transfer from the emotional to the economic area and the investor-fan is induced to sell the company's securities.

It is certainly necessary to point out that victories or defeats are not all the same and some produce more emotional, sporting and economic effects than others. These effects, which originate from the most relevant sports results, inevitably generate a more significant impact on stock prices. By way of example, on 17 April 2019, the day following the unexpected defeat of Juventus in the quarter-finals of the Champions League against Ajax, which led to the elimination of Juventus from the top European club competition with significant emotional reverberations in addition to being economic (the lack of access to the Champions League semen resulted in lower certain revenues for over 13 million euros and potential up to 33 million euros), the stock opened negotiations with a reduction of $24 \%$ compared to the previous day and was suspended to end the day with a loss of $18 \%$. On the same day, the Ajax stock opened up $10 \%$.

Table 1. Sports results (time T) and variation of share prices between $T-1$ and $T+1$.

\begin{tabular}{|c|c|c|c|c|c|}
\hline Society & Sport result & $\begin{array}{l}\text { Share price increasing between } \\
T-1 \text { and } T+1\end{array}$ & $\begin{array}{l}\text { Share price } \\
\text { unchanged }\end{array}$ & $\begin{array}{l}\text { Share price decreasing between } \\
T-1 \text { and } T+1\end{array}$ & $\begin{array}{l}\text { Total Victories, } \\
\text { Draws, Losses }\end{array}$ \\
\hline \multirow{3}{*}{ Aalborg } & Victories & $9450,54 \%$ & $4021,51 \%$ & $5227,96 \%$ & 186 \\
\hline & Draws & $4033,33 \%$ & $1915,83 \%$ & $6150,83 \%$ & 120 \\
\hline & Defeats & $3423,94 \%$ & $2819,72 \%$ & $8056,34 \%$ & 142 \\
\hline \multirow{3}{*}{ Aarhus Elite } & Victories & $7753,85 \%$ & $1913,29 \%$ & $4732,87 \%$ & 143 \\
\hline & Draws & $2627,66 \%$ & $1718,09 \%$ & $5154,26 \%$ & 94 \\
\hline & Defeats & $3722,70 \%$ & $2213,50 \%$ & $10463,80 \%$ & 163 \\
\hline \multirow{3}{*}{ Ajax } & Victories & $13249,07 \%$ & $5420,07 \%$ & $8330,86 \%$ & 269 \\
\hline & Draws & $2426,67 \%$ & $2730,00 \%$ & $3943,33 \%$ & 90 \\
\hline & Defeats & $2325,84 \%$ & $2022,47 \%$ & $4651,69 \%$ & 89 \\
\hline \multirow{3}{*}{ Benfica } & Victories & $9539,42 \%$ & $4920,33 \%$ & $9740,25 \%$ & 241 \\
\hline & Draws & $1723,94 \%$ & $1521,13 \%$ & $3954,93 \%$ & 71 \\
\hline & Defeats & $1422,58 \%$ & $914,52 \%$ & $3962,90 \%$ & 62 \\
\hline \multirow{3}{*}{ Besiktas } & Victories & $12551,44 \%$ & $208,55 \%$ & $8938,03 \%$ & 234 \\
\hline & Draws & $1716,67 \%$ & $1110,78 \%$ & $7472,55 \%$ & 102 \\
\hline & Defeats & $1614,29 \%$ & $1311,61 \%$ & $8374,11 \%$ & 112 \\
\hline \multirow{3}{*}{$\begin{array}{l}\text { Borussia } \\
\text { Dortmund }\end{array}$} & Victories & $11854,63 \%$ & $177,87 \%$ & $8137,50 \%$ & 216 \\
\hline & Draws & $3731,36 \%$ & $108,47 \%$ & $7160,17 \%$ & 118 \\
\hline & Defeats & $2320,18 \%$ & $54,39 \%$ & $8675,44 \%$ & 114 \\
\hline \multirow{3}{*}{ Brondby } & Victories & $10554,24 \%$ & 34 16,92\% & $6230,85 \%$ & 201 \\
\hline & Draws & $3428,57 \%$ & $119,24 \%$ & $7462,18 \%$ & 119 \\
\hline & Defeats & $2519,53 \%$ & $118,59 \%$ & $9271,88 \%$ & 128 \\
\hline \multirow{3}{*}{ Celtic } & Victories & $7123,51 \%$ & $17156,62 \%$ & $6019,87 \%$ & 302 \\
\hline & Draws & $811,27 \%$ & $5273,24 \%$ & $1115,49 \%$ & 71 \\
\hline & Defeats & $1114,67 \%$ & $4661,33 \%$ & $1824,00 \%$ & 75 \\
\hline \multirow{3}{*}{ Fehnerbache } & Victories & $9434,43 \%$ & $5821,25 \%$ & $12144,32 \%$ & 273 \\
\hline & Draws & 32 37,21\% & 17 19,77\% & $3743,02 \%$ & 86 \\
\hline & Defeats & $3539,33 \%$ & $1921,35 \%$ & $3539,33 \%$ & 89 \\
\hline \multirow{3}{*}{ Galatasaray } & Victories & $10742,80 \%$ & 37 14,80\% & $10642,40 \%$ & 250 \\
\hline & Draws & $2929,90 \%$ & $88,25 \%$ & $6061,86 \%$ & 97 \\
\hline & Defeats & $2423,76 \%$ & $1312,87 \%$ & $6463,37 \%$ & 101 \\
\hline
\end{tabular}

Source: own processing. 
Table 2. Sports results (time T) and variation of share prices between $T-1$ and $T+1$.

\begin{tabular}{|c|c|c|c|c|c|}
\hline Society & Sport result & $\begin{array}{l}\text { Share price increasing between } \\
T-1 \text { and } T+1\end{array}$ & $\begin{array}{l}\text { Share price } \\
\text { unchanged }\end{array}$ & $\begin{array}{l}\text { Share price decreasing between } \\
T-1 \text { and } T+1\end{array}$ & $\begin{array}{l}\text { Total Victories, } \\
\text { Draws, Losses }\end{array}$ \\
\hline \multirow{3}{*}{ Juventus } & Victories & $11043,48 \%$ & $176,72 \%$ & $12649,80 \%$ & 253 \\
\hline & Draws & $3024,59 \%$ & $32,46 \%$ & $8972,95 \%$ & 122 \\
\hline & Defeats & $2027,40 \%$ & $22,74 \%$ & $5169,86 \%$ & 73 \\
\hline \multirow{3}{*}{ Lazio } & Victories & $10457,78 \%$ & $2011,11 \%$ & $5631,11 \%$ & 180 \\
\hline & Draws & $3931,71 \%$ & $2016,26 \%$ & $6452,03 \%$ & 123 \\
\hline & Defeats & $3524,14 \%$ & $138,97 \%$ & $9766,90 \%$ & 145 \\
\hline \multirow{3}{*}{$\begin{array}{l}\text { Manchester } \\
\text { United }\end{array}$} & Victories & $4448,35 \%$ & $44,40 \%$ & $4347,25 \%$ & 91 \\
\hline & Draws & $1027,78 \%$ & $00,00 \%$ & $2672,22 \%$ & 36 \\
\hline & Defeats & $1538,46 \%$ & $25,13 \%$ & $2256,41 \%$ & 39 \\
\hline \multirow{3}{*}{ Ol. Lione } & Victories & $10950,70 \%$ & $3214,88 \%$ & $7434,42 \%$ & 215 \\
\hline & Draws & $4237,84 \%$ & $98,11 \%$ & $6054,05 \%$ & 111 \\
\hline & Defeats & $2220,95 \%$ & $98,57 \%$ & $7470,48 \%$ & 105 \\
\hline \multirow{3}{*}{$\begin{array}{l}\text { Parken } \\
\text { Sport }\end{array}$} & Victories & $12146,90 \%$ & $3915,12 \%$ & $9837,98 \%$ & 258 \\
\hline & Draws & $4037,74 \%$ & $1816,98 \%$ & $4845,28 \%$ & 106 \\
\hline & Defeats & $2428,57 \%$ & $910,71 \%$ & $5160,71 \%$ & 84 \\
\hline \multirow{3}{*}{ Porto } & Victories & $11638,67 \%$ & $7826,00 \%$ & $10635,33 \%$ & 300 \\
\hline & Draws & $2326,74 \%$ & $1719,77 \%$ & $4653,49 \%$ & 86 \\
\hline & Defeats & $2032,26 \%$ & $1422,58 \%$ & $2845,16 \%$ & 62 \\
\hline \multirow{3}{*}{ Roma } & Victories & $10547,51 \%$ & $156,79 \%$ & $10145,70 \%$ & 221 \\
\hline & Draws & $2118,75 \%$ & $65,36 \%$ & $8575,89 \%$ & 112 \\
\hline & Defeats & $1714,78 \%$ & $65,22 \%$ & $9280,00 \%$ & 115 \\
\hline \multirow{3}{*}{$\begin{array}{l}\text { Ruch } \\
\text { Chorzow }\end{array}$} & Victories & $2629,21 \%$ & $3640,45 \%$ & $2730,34 \%$ & 89 \\
\hline & Draws & $2136,84 \%$ & $2340,35 \%$ & $1322,81 \%$ & 57 \\
\hline & Defeats & $1922,62 \%$ & $3946,43 \%$ & $2630,95 \%$ & 84 \\
\hline \multirow{3}{*}{ Silkeborg } & Victories & $5236,11 \%$ & $5135,42 \%$ & $4128,47 \%$ & 144 \\
\hline & Draws & $2426,97 \%$ & $3134,83 \%$ & $3438,20 \%$ & 89 \\
\hline & Defeats & $3725,69 \%$ & $4833,33 \%$ & $5940,97 \%$ & 144 \\
\hline \multirow{3}{*}{$\begin{array}{l}\text { Sporting } \\
\text { Lisbona }\end{array}$} & Victories & $9740,59 \%$ & $5020,92 \%$ & $9238,49 \%$ & 239 \\
\hline & Draws & $2119,81 \%$ & $2725,47 \%$ & $5854,72 \%$ & 106 \\
\hline & Defeats & $2322,33 \%$ & $2221,36 \%$ & $5856,31 \%$ & 103 \\
\hline \multirow{3}{*}{ Trabzonspor } & Victories & $9045,45 \%$ & $2713,64 \%$ & $8140,91 \%$ & 198 \\
\hline & Draws & $2927,88 \%$ & $1918,27 \%$ & $5653,85 \%$ & 104 \\
\hline & Defeats & $3427,42 \%$ & $118,87 \%$ & $7963,71 \%$ & 124 \\
\hline
\end{tabular}

Source: own processing.

Analysis conducted on all official matches played by listed companies (in total 9793 matches) in the period 2004-2015.

Table 3. Sports results (time T) and variation of share prices between $T-1$ and $T+1$.

\begin{tabular}{|c|c|c|c|c|c|c|c|}
\hline \multicolumn{2}{|c|}{ Sport result } & \multicolumn{2}{|c|}{ Title increase } & \multicolumn{2}{|c|}{ Title decrease } & \multicolumn{2}{|c|}{ Title Unchanged } \\
\hline Victories & 5185 & 2302 & $44,40 \%$ & 1835 & $35,39 \%$ & 1048 & $20,21 \%$ \\
\hline Draws & 2257 & 600 & $26,58 \%$ & 1237 & $54,81 \%$ & 420 & $18,61 \%$ \\
\hline Defeats & 2351 & 527 & $22,42 \%$ & 1434 & $61,00 \%$ & 390 & $16,59 \%$ \\
\hline Total & 9793 & 3429 & $35,01 \%$ & 4506 & $46,01 \%$ & 1858 & $18,97 \%$ \\
\hline
\end{tabular}

Source: own processing.

Continuing with the analysis, all the balance sheets of the football clubs subject of the sample were analyzed and the balance sheet and income statement formats were reclassified according to the models shown below.

\section{Table 4. Reclassified Balance Sheet Model.}

\footnotetext{
Balance sheet

Fixed or fixed assets

Players Players Registration registration

Trademarks and other Intangibles

Intangible assets
} 


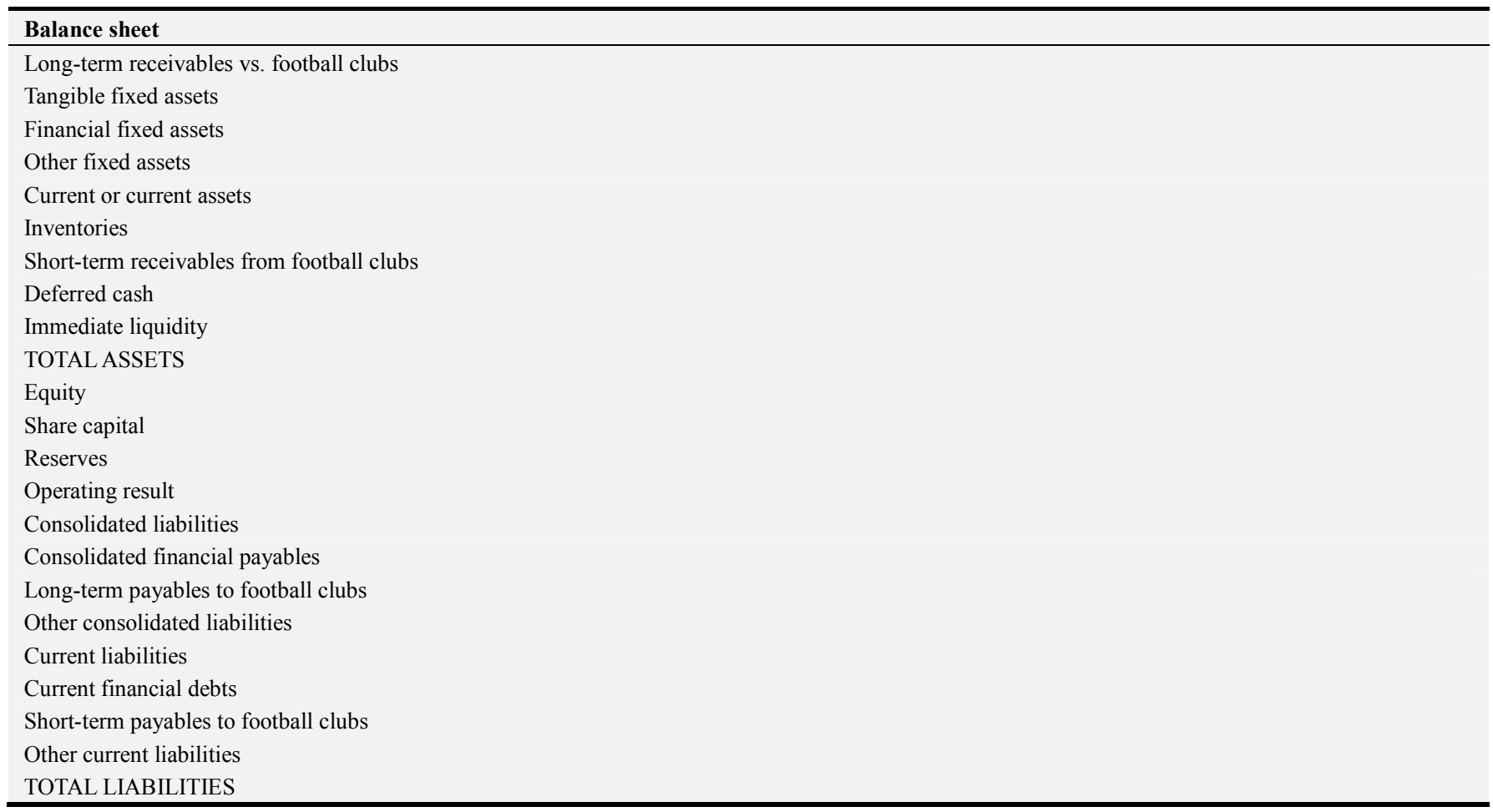

Table 5. Reclassified income statement model.

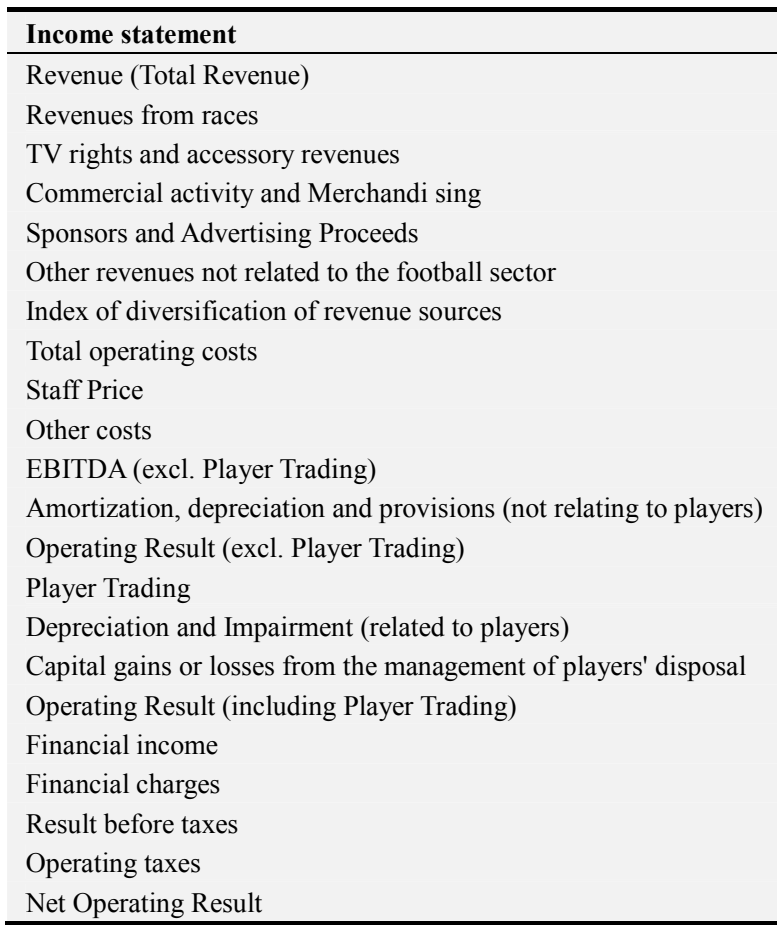

The stock price formation process for listed football companies is investigated through the multiple regression model in which the share price (dependent variable) is a function of various (independent) variables, both internal and external to the European football companies listed. This is because we analyzed the impact on the share prices of the companies of both the sports results and the macroeconomic phenomena and the business dynamics that influence the conditions of economic, financial and equity balance.

The share price makes it possible to dynamically identify the valuation that the market attributes to the economic capital of the company, since "the market value of an asset reflects its potential return and the cash flows that it expects" (Damodaran, 1976), while the book value provides a generally stable measure of the assets themselves. The chart below shows the rate of change in stock prices per year for the football companies in the sample compared to the rate of 
change in the Dow Jones Stoxx Europe Football.
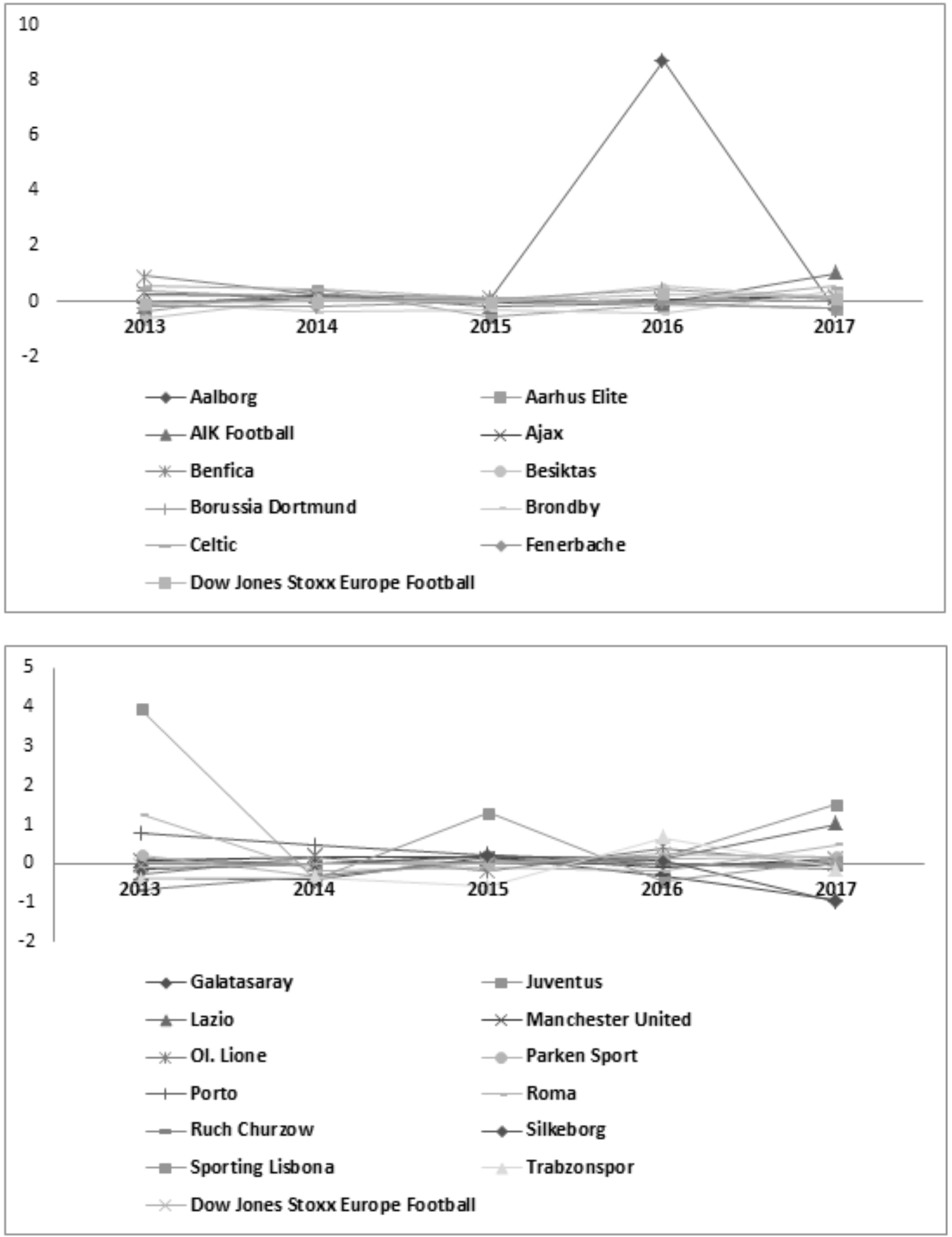

Figure 1. Share price trend of the sample companies.

\section{Methods and Data}

\subsection{Sample and Data Sources}

The companies examined are all the European ones listed on regulated markets, with the exception of AIK due to lack of price data at the time the analysis was performed.
Therefore the following listed companies were analyzed: Aalborg, Aarhus Elite, Ajax, Benfica, Besiktas, Borussia Dortmund, Brondby, Celtic, Fehnerbache, Galatasaray, Juventus, Lazio, Manchester United, Ol. Lyon, Parken Sport, Porto, Rome, Ruch Chorzow, Silkeborg, Sporting Lisbon, Trabzonspor. Table 6 describes the composition of the sample by country. 
Table 6. The composition of the sample by country.

\begin{tabular}{lllll}
\hline Country of Headquarters & $\mathbf{N}$ & Teams & Market & Total assets (year 2017, mln of euros) \\
\hline Denmark & 5 & Aalborg Boldspilklub & Copenhagen Stock Exchange & 18.80 \\
& & Aahrus Elite & Copenhagen Stock Exchange & 7.84 \\
& & Brondby & Copenhagen Stock Exchange & 25.32 \\
& & Parken Sport \& Entertainment & Copenhagen Stock Exchange & 378.45 \\
& & Silkeborg & Copenhagen Stock Exchange & 84.74 \\
France & 1 & Olympique Lyonnais & Euronext Paris & 614.21 \\
Germany & 1 & Borussia Dortmund & Frankfurter Wertpapierbörse & 478.60 \\
Italy & 3 & Juventus & London Stock Exchange & 618.48 \\
& & Lazio & London Stock Exchange & 204.54 \\
& & As Roma & London Stock Exchange & 436.14 \\
Netherlands & AFC Ajax & Euronext Amsterdam & 246.08 \\
Poland & 1 & Ruch Chorzow & Warsaw Stock Exchange & 4.73 \\
Portugal & 1 & Benfica & Euronext Lisbon & 506.06 \\
& 3 & Futebol Clube do Porto & Euronext Lisbon & 378.42 \\
& & Sporting Lisbona & Stockholm Stock Exchange & 316.49 \\
Sweden & & AIK Football & London Stock Exchange & 13.51 \\
United Kingdom & 1 & Celtic & New York Stock Exchange & $1,974.61$ \\
& 2 & Manchester United & Istanbul Stock Exchange & 138.69 \\
Turkey & & Besiktas & Istanbul Stock Exchange & 166.75 \\
& 4 & Fenerbahce Sportif Hizmet & Istanbul Stock Exchange & 186.65 \\
& & Galatasaray & Istanbul Stock Exchange & 94.33 \\
TOTAL & & Trabzonspor Sportif Yatir & & \\
\hline
\end{tabular}

\subsection{Methodology: The Econometric Approach}

The stock price process of listed football companies is being investigated through the model in which the share price (dependent variable) is a function of sports results (independent variables) and firm-level control variables were added. Some of these are economic, financial and asset variables and the indicator of diversification of revenue. The financial data (in millions of euro) was obtained by consulting the Annual Report of football clubs. To calculate the indicator of diversification of revenue sources (IDR) we used a variant of the Gini indicator and not the Herfindahl Index (HI) for the several criticisms lie against the HI, both in general and in particular, for through faulty or inconsistent application and inappropriate calibration for the number of firms comprised an industry and the variance in market share distribution [27]. The Gini indicator is used to calculate the distribution of wealth in some countries and, in our analysis, we have assumed that the sources of revenue behave exactly like the income of a given country. The general formula is:

$$
\mathrm{G}=\frac{1}{n}\left(n+1-2 \frac{\sum_{i=1}^{n}(n+1-i) y_{i}}{\sum_{i=1}^{n} y_{i}}\right)
$$

In our calculation there is a variant due to the fact that we considered the maximum equality in the distribution equal to 1 and the maximum inequality equal to 0 , while in the Gini indicator, the opposite occurs; we can therefore consider our indicator in the following way: IDR $=1$-GINI.

Further mathematical steps have enabled us to arrive at a simplified formulation that can be used for our specific case:

$$
\operatorname{IDR}=\left(\frac{2}{n-1}\right) *\left(\sum_{i=1}^{n-1} y_{i}\right)
$$

A detailed description of all variables, their definition and their source are provided in the Table 7.

Table 7. Measurement of all dependent and independent variables.

\begin{tabular}{llll}
\hline Variable & Measure & Label & Source \\
\hline $\begin{array}{l}\text { Dependent variable } \\
\text { Stock price }\end{array}$ & share price as of December 31 of each year & SP & markets \\
Independent variables & This is a score (score) determined each year based on the results achieved by each & UEs & www.uefa.com \\
UEFA Coefficient score & team in European competitions in the previous 5 seasons & REV & balance sheet \\
Revenue & Total revenue (which does not include the "other revenues" item). & TA & balance sheet \\
Total assets & Total assets (euro) of the clubs/10 millions & FD & balance sheet \\
Financial debts & Includes both current financial debts and consolidated financial debts & ROE & balance sheet \\
Return on equity & Net income/shareholder's equity & IDR & balance sheet \\
Index of diversification of revenue & $\left(\frac{2}{n-1}\right) *\left(\sum_{i=1}^{n-1} y_{i}\right)$ & NI & balance sheet \\
Net income & Profit or loss after expenses & &
\end{tabular}


Table 8 reports the descriptive statistics of all dependent and independent variables used in the study.

During the period examined, the average value of the shares of the companies examined was Euro 7.01. With regard to sports performance indicators, average growth was recorded in the period examined. The positive average change in the financial indicators of the companies examined and the particularly marked variability of the profitability indicators with respect to the other indicators is also evident.

Table 8. Descriptive statistics.

\begin{tabular}{llllll}
\hline Variable & Mean & Standard deviation & Minimum & Maximum & Number of observations \\
\hline SP & 7.011646 & 2.016239 & 3.258096 & 11.89989 \\
UEs & 10.53152 & .9594985 & 8.402905 & 11.86275 \\
REV & 24.57715 & 1.423081 & 21.55765 & 27.50484 \\
TA & 25.42941 & 1.540096 & 20.49126 & 28.31139 \\
FD & 24.06215 & 2.694644 & 13.75181 & 27.21148 & 124 \\
ROE & -240.5758 & 1672.213 & -7345 & 12299 & 131 \\
IDR & 593.3058 & 185.7749 & 110 & 980 & 123 \\
NI & 22.50055 & 1.77177 & 16.84947 & 132 & 121 \\
\hline
\end{tabular}

Notes: Data relate to the 2012 to 2017 period.

The stock price formation process for listed football companies is investigated through the following panel regression model (baseline estimation):

$$
Y_{i t}=\beta_{1}+\beta_{2} U_{E s} \text { it }+\beta_{3} R V_{i t}+\beta_{4} T_{i t}+\beta_{5} \mathrm{FD}_{i t}+\beta_{6} \mathrm{ROE}_{\mathrm{it}}+\beta_{7} \mathrm{IDR}_{\mathrm{it}}+\beta_{8} \mathrm{NI}_{\mathrm{it}}+\varepsilon_{\mathrm{it}}
$$

where y represents SP (Stock price), $i$ and $t$ denote the firm and the year, and the error terms $\varepsilon_{\mathrm{it}} \sim \operatorname{IID}\left(0, \sigma^{2}\right)$ account for possible firms-level stochastic shocks that may affect the dependent variable in each regression. Since due to the possible endogeneity of some explanatory variables, the estimation could produce biased results, we estimated each equation by one-year lagging all regressors. This allowed us to mitigate endogeneity concerns and to control for withinfirm dynamics. Time-fixed effects in the model was included to account for any time-invariant firm characteristics that might affect firm-level outcomes unobserved heterogeneity.

Unlike other scientific papers $[25,5]$ that analyze the impact of sports results on stock prices of football clubs listed in the short term, or in the time horizon of the days immediately preceding and following the sporting result, our scientific work analyzes the phenomenon in a medium-term reference time horizon, or on an annual basis.

The average time horizon, ie referred to the year, makes it possible to evaluate comparatively the relevance as determinants of the dynamics of share prices both in sports results, and internal company variables without compromising and influencing the balance a priori among these variables as potential determinants of stock prices. In fact, where the impact was assessed exclusively within the time horizon of a few days, the emotional component, which in the short term has a preponderant impact, would greatly influence the significance of the analysis nor would it be possible to detect the impact in a time horizon of less than fiscal year of various internal company variables that deserve instead to be analyzed and weighed in the same way as sports results.

\section{Empirical Results}

The estimations have been carried out by employing the STATA 15 econometric software. The results achieved are reported in Table 9.

Table 9. Estimation results for the baseline model. Dependent variable: SP.

\begin{tabular}{lllll}
\hline & Coef. & t & P $>|\mathbf{t}|$ & [95\% Conf. Interval] \\
\hline UEs & $.5941054(.1914406)$ & 3.10 & 0.007 & .1860594 \\
REV & $.1596851(.0745297)$ & 2.14 & 0.049 & .0008288 \\
TA & $.1255847(.2973027)$ & 0.42 & 0.679 & -.508101 \\
FD & $.0211085(.0363462)$ & 0.58 & 0.570 & -.0563616 \\
ROE & $.0000121(5.88 \mathrm{e}-06)$ & 2.06 & 0.057 & $-4.36 \mathrm{e}-07$ \\
IDR & $.0000809(.0002217)$ & 0.36 & 0.720 & -.0003917 \\
NI & $.0964238(.0374145)$ & 2.58 & 0.021 & .0166768 \\
Year & & & & .0985785 \\
2013 & $-.158322(.1378396)$ & -1.15 & 0.269 & .0000246 \\
2014 & $.111(.1757754)$ & 0.63 & 0.537 & .0005534 \\
2015 & $.1635619(.2024955)$ & 0.81 & 0.432 & .26362 \\
2016 & $.2585747(.2213971)$ & 1.17 & 0.261 & -.2680472 \\
2017 & $.3295542(.2378305)$ & 1.39 & 0.186 & -.2133221 \\
Const & $-8.685859(9.734345)$ & -0.89 & 0.386 & -.1773696 \\
$R$-squared (Within) & 0.7766 & & & .1354762 \\
\hline
\end{tabular}

Notes: Fixed-effects estimations. Cluster-robust standard errors in parentheses. 
The specification checks (Hausman test, used to discriminate between the use of random effects and fixed effects), therefore, seem to provide evidence that the estimations of models is stable and robust. The results reveal that the stock price process of listed football companies evidence i) positively and significant link with sporting performance (UEs), ii) positively and significant link with economic performance (REV, ROE and NI), and iii) positively link with size of listed football companies.

The positive impact of sports results on stock prices of listed football clubs can be irrationally justified by the emotional component that drives the choices of the investor, who may often also a be fan and therefore particularly sensitive in the short term to sports results, and rationally by significant impact that the sporting results have both on the assets, through the increase in value of the assets of the Balance Sheet (value of the players, brands, etc.), and on the income statement due to the higher revenues for sponsors, advertising revenues and TV rights also linked to participation in international competitions. As our empirical analysis shows, however, obtaining good sports results is a necessary but not sufficient condition to achieve success even in the financial markets.

Beyond the impact of sports results, in order to be able to positively influence the financial markets, it is fundamental for a listed football club to pursue a balanced economic management, definitively abandoning the management model based on the patronage more or less passionate or interested of the pseudo-fan owner. Basing management instead on rigid managerial rules, based on efficiency, on the reduction of management costs, above all those linked to salaries. The diversification of activities and the related sources of revenue, exploiting the popularity of sport for commercial purposes must be considered. Infrastructure investments essentially linked to the owned stadium that guarantees huge returns in the medium term are important. Investments in the youth sector that allows players to trade players in the medium term, guaranteeing an additional source of revenues and capital gains are also essential.

Our analysis dispels the a priori myth according to which investing in listed soccer companies is inadvisable, since, as the empirical data show, where a football club successfully pursues the sporting aim without compromising the managerial balance, as done for example by Juventus in the recent years, the investment in listed football companies can generate excellent returns. In addition to our empirical analysis, this conclusion is also supported by the 21 st edition of the Boston Consulting Group (Bcg) "Value Creators", published in August 2019, which shows that the Italian company listed on the stock exchange that during the last five years has been able to create greater value for investors was Juventus. Indeed, the analysis shows that the Turin club has generated a Total Shareholder Return (Tsr) of 36\%. The TSR is a metric elaborated by Bcg that expresses the overall return of the equity investment by measuring the variation of the price of the shares and the return of the dividends distributed and reinvested.

For football clubs, listing on the stock market certainly represents an interesting and stable source of financing, but presupposes, as our empirical analysis shows, greater economic-financial rigor in management and a more careful diversification of its activities and the relative sources of revenue. In fact, it is strategically fundamental for a football club to increase the diversification of its sources of revenue, as this would first of all guarantee greater income flows, for example by exploiting the company's brand for commercial purposes. Moreover a greater diversification of sources of revenue would ensure greater management stability by reducing the business risk as it would untie - at least partially the economic fortunes of the company from sports results or, in general, from the turnover that revolves around the football universe. In order to guarantee greater stability in revenues, means being able to have the ownership and the full control of sports facilities and in particular of the stadium. To diversify their sources of revenue by offering products and services complementary to sports entertainment. Having an efficient management (selection and training) of new talents, exploiting the «brand» in order to be able to benefit in commercial terms from the popularity of the team.

For sports clubs, therefore, a qualitative leap in the corporate culture is absolutely necessary, based on several solid company principles, on a clear and defined strategy in the medium-long term, on cost-effectiveness and managerial and organizational efficiency. Also on the diversification of revenue sources and therefore on a greater orientation towards commercial development, marketing and communication, on the increase in capital solidity, on the infrastructural investment linked to the ownership stage that guarantees huge returns in the medium term as well as on investments in the youth sector that allows players to trade players in the medium term, guaranteeing an additional source of revenue and capital gains.

\section{Conclusions, Implications and Future Research Lines}

The empirical survey carried out seems to offer elements that allow one to reach the research objectives presented in the introduction. First of all, there is a rather accentuated link between sports results and share price performance, especially in cases of defeat or draw and this can obviously be traced to the consideration that investors on the stock market, in the case of football clubs, are often fans and irrationally tend to transfer the negative feeling that derives from the emotional area to the economic one, so as to be induced to sell the company's securities. Based on the results, hypothesis 1 is accepted.

Secondly, the results of the econometric model return results allow us to judge as good the ability of the same models to explain the variance of the dependent variable and this makes the analysis of the results that emerged possible 
and meaningful. The second hypothesis predicts a positive relationship between the market performance and the economic-financial profile of football clubs. These results confirm the hypothesis. The estimates received from the analysis carried out for the entire period make it possible to highlight how not only the competitive results but also the balance sheet variables affect and clearly influence the stock prices of the football clubs. Among these, in particular, we noted the very significant and positive link between share prices and economic performance. In the econometric exercise carried out, the positive relationship on the stock market prices of the total assets of the companies under investigation was also highlighted.

The positive impact of sports results on stock prices of listed football clubs can be justified - as mentioned irrationally by the emotional component that drives the choices of the investor, often a fan and therefore particularly sensitive in the short term to sports results, and rationally by the significant impact that the sports results have on both the assets, through the increase in the value of the balance sheet assets (value of the players, brands, etc.), and on the income statement due to higher revenues for sponsors, advertising revenues and TV rights also linked to participation in international competitions. As our empirical analysis shows, however, obtaining good sports results is a necessary but not sufficient condition to achieve success even in the financial markets. Beyond the impact of sports results, in order to be able to positively influence the financial markets, it is fundamental for a listed football club to pursue a balanced economic management. Basing management on rigid managerial rules, based on efficiency, on the reduction of management costs, above all those linked to salaries, on the diversification of activities and the related sources of revenue, exploiting the popularity of sport for commercial purposes, on infrastructure investments essentially linked to the owned stadium that guarantees huge returns in the medium term as well as on investments in the youth sector that allows players to trade players in the medium term, guaranteeing an additional source of revenues and capital gains.

Our empirical analysis therefore dispels the a priori myth according to which investing in listed soccer companies is inadvisable, since, as the empirical data show, where a football club successfully pursues the sporting aim without compromising the managerial balance the investment in clubs listed can generate excellent returns.

Finally, from the analysis of the data it seems to emerge that the markets prove to be able to read in real time both the most relevant sports results that inevitably generate a more significant impact on share prices and the development of corporate phenomena, expressed through the financial indicators considered for the purpose of this research. And this leads us to reflect, in a possible future development of this research, on the other external phenomena [26] that are extraneous to the economic-patrimonial fundamentals of football clubs and to those of the system in which they operate, capable of showing effects on the stock price dynamics of the same.

\section{References}

[1] Allen F. (1990), The Market for Information and the Origin of Financial Intermediation, in «Journal of Financial Intermediation», 1, 1, pp. 3-30.

[2] Barros, C. P. \& Leach, S. (2006). Performance evaluation of the English premier football league with data envelopment analysis. Applied Economics, 38, 1149-1458.

[3] Bell, A. R., Brooks, C., Matthews, D. and Sutcliffe, C. (2011) Over the moon or sick as a parrot? The effects of football results on a club's share price. Applied Economics, 44 (26). pp. 3435-3452. ISSN 1466-4283 doi: 10.1080/00036846.2011.577017 Available at http://centaur.reading.ac.uk/20978/

[4] Benkraiem R., Louhichi W. and Marquès P. 2009. Market reaction to sporting results: The case of European listed football clubs, Management Decision 47 (1), p. 100-109.

[5] Berument, H., Ceylan, N. B. \& Gozpinar, E. (2006). Performance of soccer on the stock market: evidence from Turkey. The Social Science Journal, 43, 695-699.

[6] Boido, C. \& Fasano, A. (2007). Football and mood in Italian stock exchange. The Icfai University Journal of Behavioral Finance, 4, 32-50.

[7] Boscá, J. E., Liern, V., Martínez, A. \& Sala, R. (2009). Increasing offensive or defensive efficiency? An analysis of Italian and Spanish football. Omega-The International Journal of Management Science, 37, 63-78.

[8] Campbell T. S.-Kracaw W. A. (1980), Information Production, Market Signalling, and the Theory of Financial Intermediation, in «Journal of Finance», 35, 4, 863-882.

[9] Carmichael, F. Thomas, D. \& Ward, R. (2000). Team performance: The case of English premiership football. Managerial and Decision Economics, 21, 31-45.

[10] Chan Y. S.-Thakor A. V. (1987), Collateral and Competitive Equilibria with Moral Hazard and Private Information, in «Journal of Finance», 42, 2, 345-363.

[11] Dawson, P. \& Dobson, S. (2002). Managerial efficiency and human capital: An application to English association football. Managerial and Decision Economics, 23, 471-486.

[12] Demir, E., \& Rigoni, U. (2017). You lose, I feel better: Rivalry between soccer teams and the impact of schadenfreude on stock market. JSE, 18 (1), 58-76.

[13] Duque, J. \& Ferreira, N. A. (2007). Explaining share price performance of football clubs listed on the Euronext Lisbon. Working Paper Series, Retrieved from http://ssrn.com/abstract=675633.

[14] Edmans, A., Garcia, D. \& Norli, O. (2007). Sports sentiment and stock returns. The Journal of Finance, 62, 1967-1998.

[15] Fama E. F. (1970), Efficient Capital Market: A Review of Theory and Empirical Work, in «Journal of Finance», 25, 2, pp. 383-417.

[16] Floros C. (2014), Football and Stock Returns: New Evidence, International Conference on Applied Economics (ICOAE) 2014, Procedia Economics and Finance 14 (2014) 201-209. 
[17] Gamble, D., J. Bradley, A. McCarren and N. M. Moyna, (2019). Team performance indicators which differentiate between winning and losing in elite Gaelic football. International Journal of Performance Analysis in Sport, 19 (4): 478-490.

[18] Gerrard, B. (2005). A resource-utilization model of organizational efficiency in professional sports teams. Journal of Sport Management, 19, 143-169.

[19] Heij, R., Vermeulen, P. \& Teunter, L. (2006). Strategic actions in European soccer: do they matter? The Service Industries Journal, 26, 615-632.

[20] Hino Y., Takeda F. (2019). Market reactions to sport sponsorship announcements: Comparison between sponsors and their rivals, Sport Management Review, Available online 27 February 2019.

[21] Hoehn, T. \& Szymanski, S. (1999). The americanization of European football. Economic Policy, 28, 205-240.

[22] Millon M. H.-Thakor A. V. (1985), Moral Hazard and Information Sharing: A Model of Financial Information Gathering Agencies, in «Journal of Finance», 40, 5, 14031422.

[23] Morrow S., Robinson L., The FTSE-British Olympic Association Initiative: A resource dependence perspective, Sport Management Review, Volume 16, Issue 4, November 2013, Pages

413-423. https://doi.org/10.1016/j.smr.2013.01.002

[24] Ozawa, T., Cross, J. \& Henderson, S. (2004). Market orientation and financial performance of English professional football clubs. Journal of Targeting, Measurement and Analysis for Marketing, 13, 78-90.
[25] Renneboog, L. D. R., \& Vanbrabant, P. (2000). Share Price Reactions to Sporty Performances of Soccer Clubs listed on the London Stock Exchange and the AIM. (CentER Discussion Paper; Vol. 2000-19). Tilburg: Finance.

[26] Richardson S., Sloan R., and You H. (2012), What Makes Stock Prices Move? Fundamentals vs. Investor Recognition, in «Financial Analysts Journal», 68, 2.

[27] Roberts T. (2014), When Bigger Is Better: A Critique of the Herfindahl-Hirschman Index's Use to Evaluate Mergers in Network Industries, in «Pace Law Review», 34, 2.

[28] Samagaio A., Couto E., Caiado J. (2009), Sporting, financial and stock market performance in English football: an empirical analysis of structural relationships, Working Paper.

[29] Szymanski, S. \& Kuypers, T. (1999). Winners and Losers: The Business Strategy of Football. London: Viking.

[30] Szymanski, S. (2001). Income inequality, competitive balance and the attractiveness of team sports: some evidence and a natural experiment from English soccer. The Economic Journal, 111, 69-84.

[31] Thompson, R. B., Olsen, C. \& Dietrich, J. R. (1987). Attributes of news about firms: an analysis of firm-specific new reported in the Wall Street Journal Index. Journal of Accounting Research, 25, 245-274.

[32] Zuber, R. A., Yiu, P., Lambc, R. P. \& Gandar, J. M. (2005). Investor-fans? An examination of the performance of publicly traded English Premier League teams. Applied Financial Economics, 15, 305-313. 